\title{
Web-Based Design Of Minangkabau Songket Motif Digital Catalog
}

\author{
Muhammad Habib Yuhandri \\ Universitas Putra Indonesia YPTK Padang \\ abghasim@gmail.com
}

\begin{abstract}
Indonesia's richness in culture requires special attention in terms of its preservation, therefore it is important for us to maintain and preserve Songket cloth, especially its motifs which are rich in the philosophy of local wisdom so that they can be passed down to the next generation. Information technology can be used to solve these problems, especially for digital catalogs that can be used to help preserve Songket cloth through digitizing the motifs on each cloth. Through digitization, it will be easy to get information about the shape of the motif, the name of the motif, the philosophy contained in the motif through an application. The purpose of this study was to build a digital catalog system on the WEB-based Minangkabau Songket motif. The development of this system is carried out by means of data collection, system analysis, system design, and system implementation. This system is built using the PHP programming language and MySQL database. The results of this study provide a tool in the form of a Minangkabau Songket Motif Digital Catalog system. The benefits of research provide the development of deep catalog technology to store information related to Minangkabau Songket motifs.
\end{abstract}

Keywords: Songket, Motif, Website, PHP MySQL, Digital.

\section{Introduction}

Indonesia is one of the countries in the world that has various ethnic groups that have various kinds of cultures, ranging from regional languages, customs, traditional clothes, traditional houses, traditional arts, customary law. One of the cultures that is also important to maintain is traditional clothing where this culture has been passed down from time immemorial by our ancestors from one generation to the next. Various kinds of diversity of traditional clothes in Indonesia, ranging from batik, songket, sasirangan, ulos, bugis sarong, lurik, gringsing, tapis, Dayak weaving, besurek, ulap doyo, poleng, jumputan.

One of the famous traditional clothes is the songket, songket is a type of traditional woven fabric that can be found in several regions in Indonesia. Songketproducing areas include Sumatra, Java and Bali, Sulawesi and Nusa Tenggara[1]. There are several threads used in songket fabrics, such as cotton, silk, gold, and silver threads, the decoration is made up of gold threads, silver threads, or threads of different colors with the basic color of the woven[2]. Songket yarn is generally a type of gold, silver (Macau thread), and other colored cotton thread[3],[4],[5],[6].

Each songket-producing area has its own are needed to be used as guidelines in making research. characteristics, there are specificities for weaving areas The research framework is the concept or sequence of in Sumatra, additional feed in the form of gold or silver activities to be carried out in a study. So that the steps thread songket, especially seen on songket cloth in taken by the author in this design do not deviate from West Sumatra, Palembang, South Sumatra, Nagroe the subject matter and are easier to understand. The Aceh Darussalam, Riau, Jambi, Bengkulu., Bangka and stages can be described in Figure 1.

Belitung, Lampung, East Sumatra, and North Sumatra.

Indonesia's richness in culture requires special attention in terms of its preservation, therefore it is important for us to maintain and preserve songket cloth, especially its motifs which are rich in the philosophy of local wisdom so that they can be passed down to the next generation. Information technology can be used to solve these problems, especially for digital catalogs that can be used to help preserve songket cloth through digitizing the motifs on each cloth. Through digitization, it will be easy to get information about the shape of the motif, the name of the motif, the philosophy contained in the motif through an application.

In this study, the problems discussed are how to design and build a website so that everyone can know the songket motifs and the process of songe hypothesis obtained is that the website design will be able to facilitate users in accessing the information contained therein. Then the existence of this website makes it easier for the public to understand the Minangkabau songket motifs and the meanings they contain.

\section{Research Method}

The research methodology used can be explained in the form of stages or steps in carrying out activities starting from recording data and collecting several reports that 


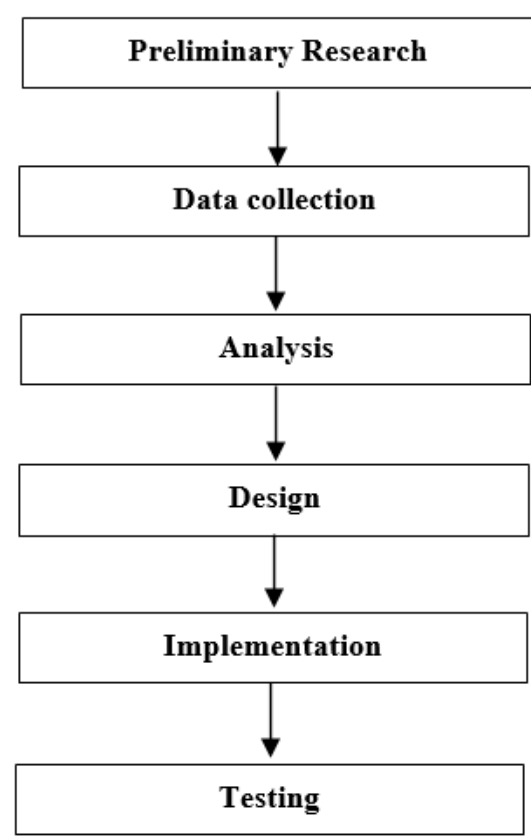

Fig. 1 Research Framework

\subsection{Preliminary Research}

Preliminary research is the first step in conducting research by first analyzing the problems that will be developed. The goal after implementing the application to be developed can help users (users) in utilizing the system.

\subsection{Data Collection}

The data collection stage is a decisive stage in an 2.6 System Test application development process. The success or failure of an application depends on the data collected.

\subsection{Analysis}

In order to conduct research, the authors analyze the data that has been collected and analyze the system that will be run as a solution to the problem formulation obtained.

\section{A. Data Analysis}

The data obtained were analyzed and grouped by category.

\section{B. Process Analysis}

The method used in this research is to analyze the Songket motif data and adapt it to the existing meaning and philosophy

\section{System Analysis}

System analysis is the basis for plannin the system to be implemented. System analysis is done philosophy of local wisdom that can be learned by to build a system. This system requires some data to be everyone, but it is still constrained by the limited included in the application. Some of the data that will information available about the Minangkabau Songket be included include Songket motif image data and other motif. The hope is that information about the data. The data will be entered into the database to be Minangkabau Songket motif, both about the shape of well organized.
The design stage aims to make the research designed according to the objectives so that it does not deviate from the research objectives. The process of collecting data will be carried out to design the system as an object of research. The design will use UML as a design model to be organized and structured by design[7].[8].

\section{A. Use Case Diagram}

In designing this application, the use case diagram consists of two actors, namely: admin and visitors. These two users will become application users who can carry out activities in the application according to their rights.

\section{B. Activity Diagram}

The activity diagram depicts the flow of activities that occur in the application, starting with how each flow begins and how they end.

\subsection{Implementation System}

System implementation is the stage of implementing a system that has been designed or designed so that the system that has been created can be operated and used optimally according to needs[9]. At the implementation stage of the catalog system application on the Songket motif in West Sumatra, program hosting will be carried out on web hosting so that later the application can be accessed by the public[10].

After the implementation phase is complete, the author also conducts tests aimed at testing the system that has been designed, correcting the system that has been built based on the level of system efficiency as a solution in solving the problems that have been formulated[11]. Testing is done by seeing whether the application is running correctly and by the design carried out[12].

\section{Result and Discussion}

The discussion of this research starts from the system analysis process that is used as a parameter for measuring the performance of the system to be designed. The analysis was conducted aiming to find out the problems that occur in the Minangkabau Songket motif so that the development and design of the new system can be carried out properly and by the wishes and needs.

the motif, the name of the motif, and the area of origin

\subsection{Model Design}


of the Songket weave, can be easily obtained through an application that can help preserve the Songket cloth. The system design that uses the PHP programming language and MySQL database is expected to provide convenience for many parties. The general system design procedure for system development in building this application consists of several stages, including designing:

\section{A. Data Input}

It includes supporting data as input for the manufacturing system such as input data for Minangkabau Songket motifs, including the meanings contained therein.

\section{B. Data Output}

From the input data above, it can be used as a system output. The output on the current system is information about Songket, information about the meaning contained in the Songket motif.

\section{Process}

The design which is an experience is a working system, what processes are used, starting from the entry of input data which is then processed by the system so that it becomes data output.

\subsection{Design System}

The system design carried out consists of a Use Case Diagram, Sequence Diagram, Activity Diagram, Class Diagram design. The target to be achieved at this stage is that the system design can prepare a detailed, useful, easy, efficient, and effective design:

\section{A. Use Case Diagram}

Use case diagrams to describe who and what processes will be carried out by the actor. Actors are people who interact with the system[13]. Use case diagrams will describe the processes carried out by actors on the system. Those who act as actors are super admin/leaders and visitors[14],[15]. To be clearer, the use case diagram can be seen in Figure.2.

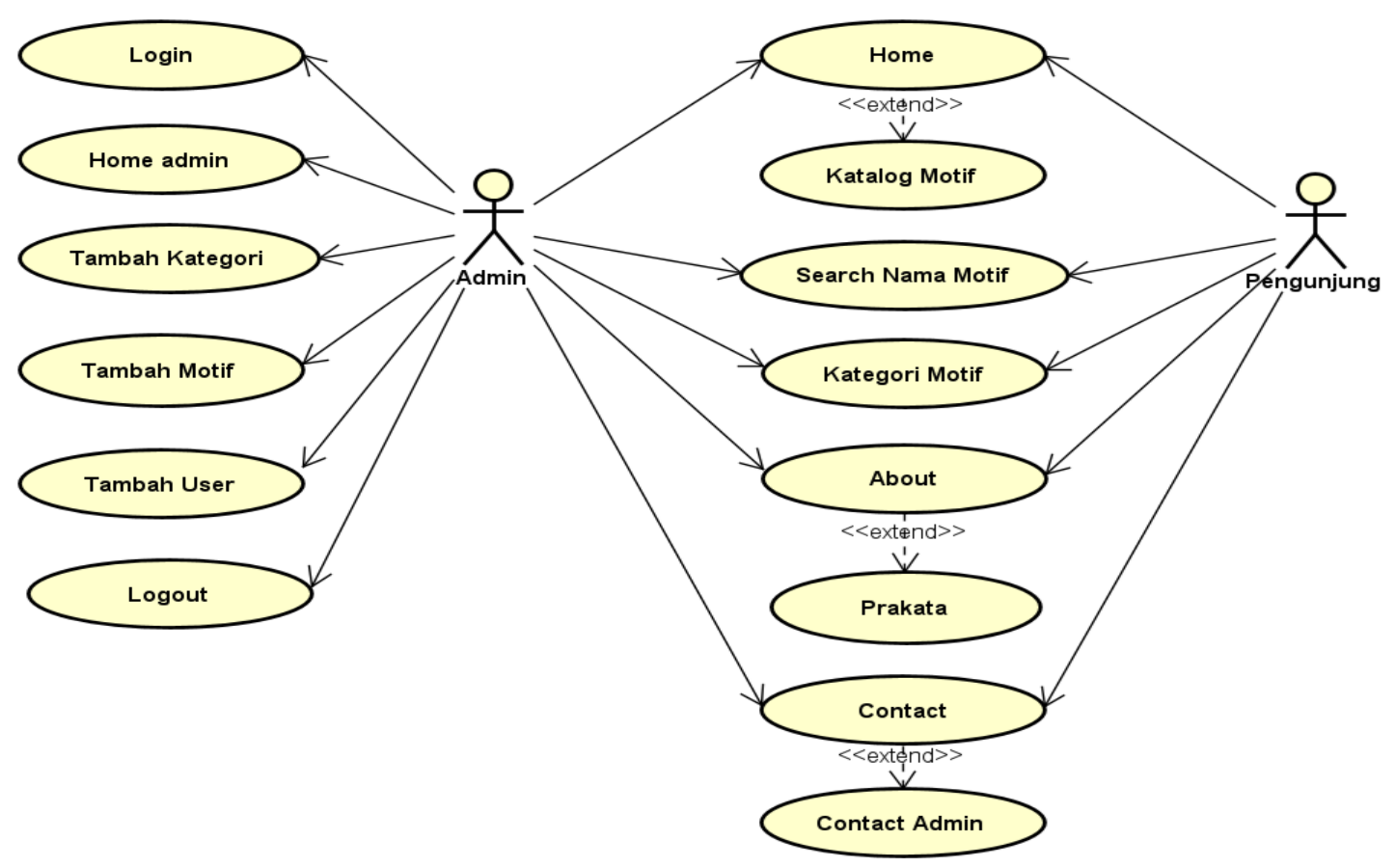

Fig. 2 Use Case Diagram

Figure. 2 explains that the actors involved in the system completion of actions originating from the source. consist of admins and visitors. The admin function acts Activity diagrams are the same as flowcharts that as the manager of the entire system and visitors can describe the processes that occur between actors and only view the Songket catalog. the system[16],[17].

\section{B. Activity Diagram}

The following is an overview of the admin activity

Activity diagram charts are used to show actions and diagram which can be seen in Figure.3. some of the basic transitions triggered by the 


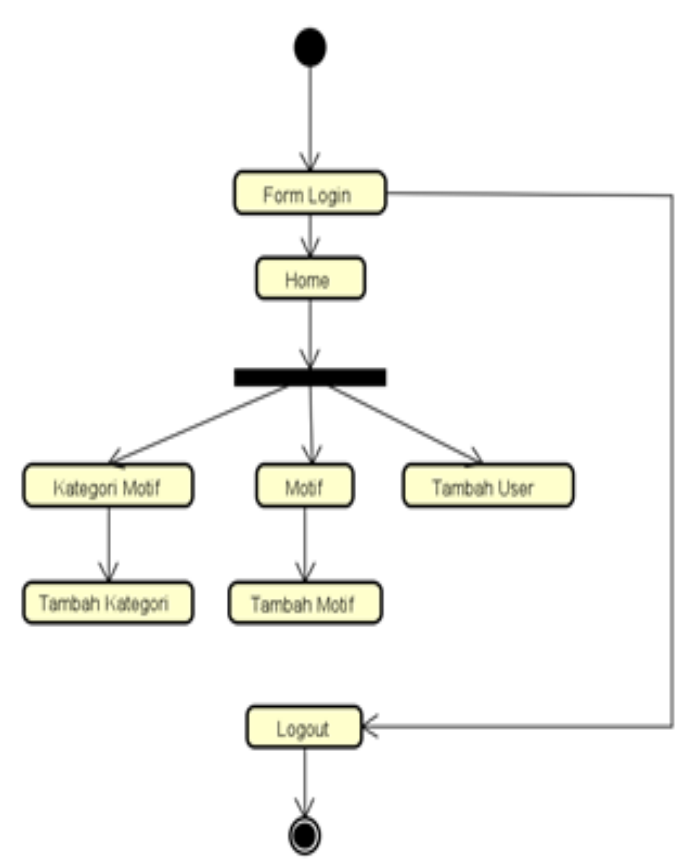

(i)

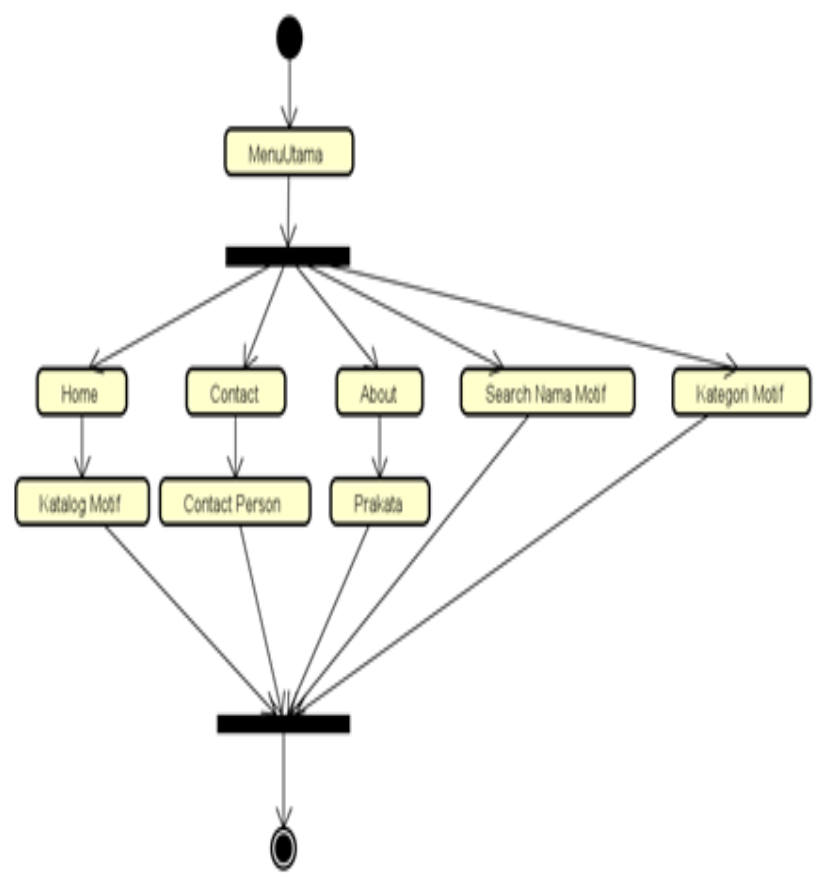

(ii)

Fig.3 Activity Diagrams

\subsection{Detailed System Design}

\subsection{System Implementation}

Detail design is a development of the previous global System implementation is the stage of implementing design, in this detailed design, we will discuss the and testing the new system based on the results of the output, input, file design[17]. So that with the detailed analysis and design that have been done previously. design it will be known directly what is produced from With the implementation of the designed system, the the system, it will be known directly what is produced results can be operated and used optimally and as from the newly developed system.

The design was designed by the author based on the needs and interests to obtain more accurate information for all interested parties. In this detailed design, a detailed description will be carried out by paying attention to the results that will be obtained in detail. The following are the results of the catalog system design that was designed Figure.4.

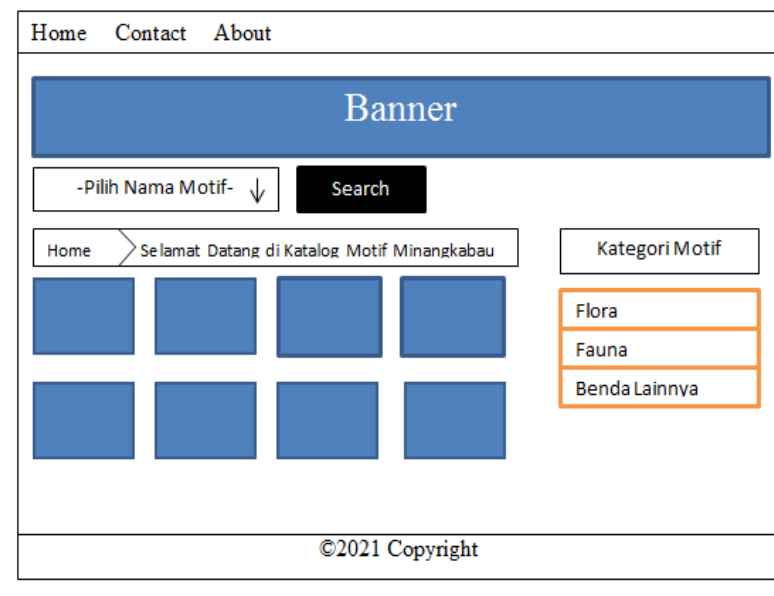
needed. The following are the results of the implementation of the resulting system in Figure.5.

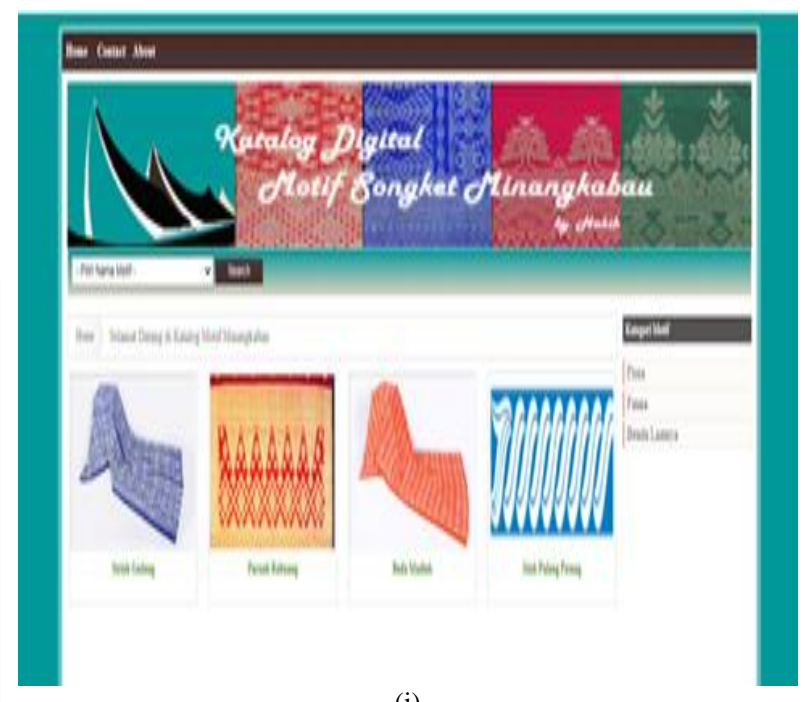

(i)

Fig.4 Design System 


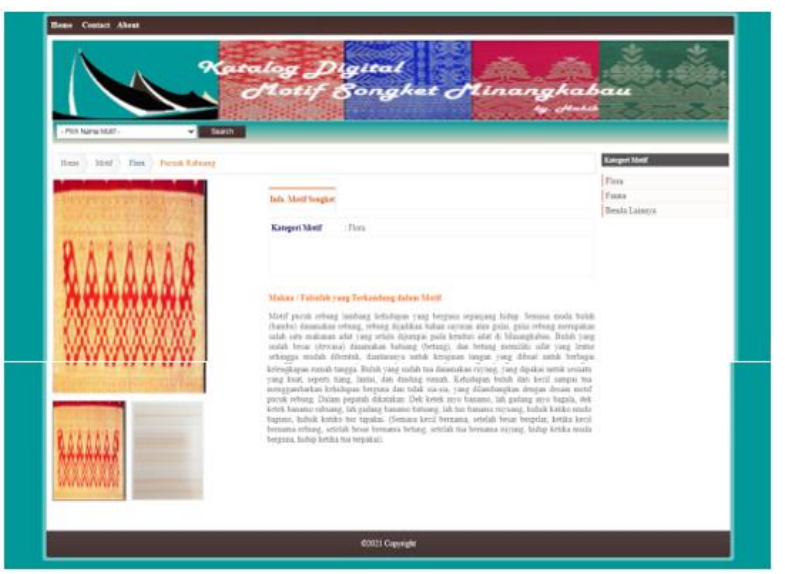

(ii)

Fig.5 Implementation System

Figure. 5 On the Home Menu of the Songket Motif

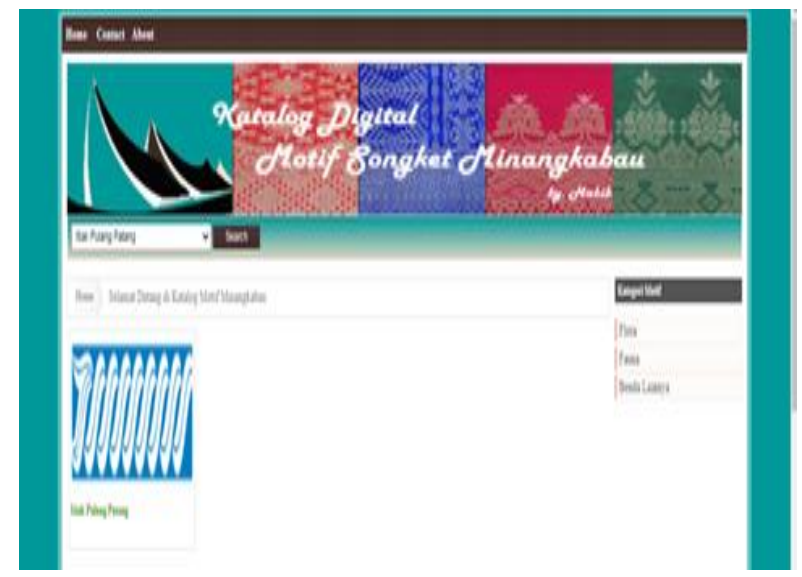

(iii)

Fig.6 Flora Category Display

Catalog Information System, it contains Contact, There is Figure. 6 also a menu to search which is About, Motif Category information, as well as the useful to make it easier for users to find certain motifs display of Songket motifs that can be opened and according to what they are looking.

display information.

The system has also provided a facility to view motifs per category, by clicking on one category the entire category will appear in the middle screen, as shown in Figure. 6 below is the Flora category display.

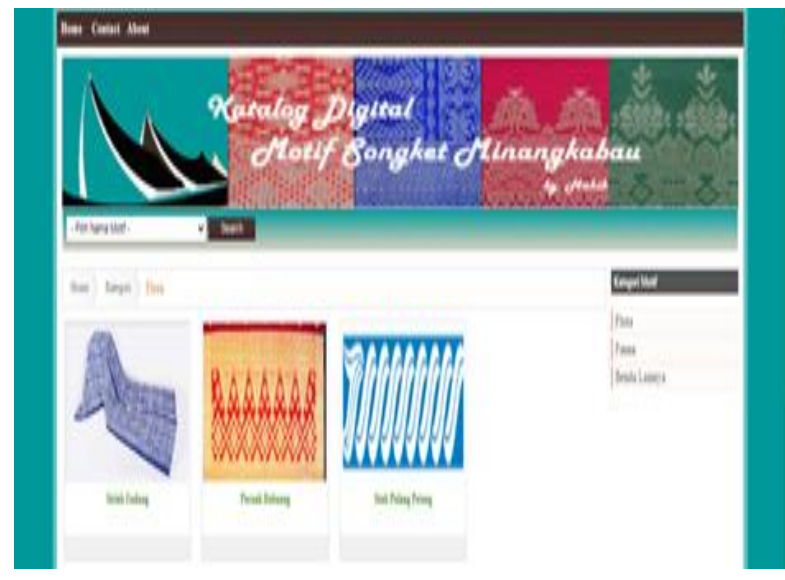

(i)

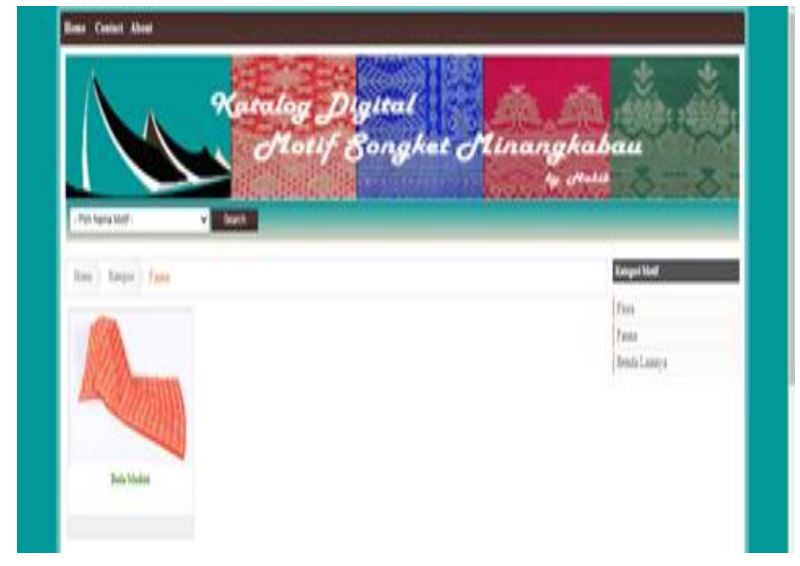

(ii)

\section{Conclusion}

This Digital Catalog of Minangkabau Motif Songket is a system that functions to provide lessons in the form of information on the names of songket motifs and the meanings contained in the songket motifs, so it is hoped that this ancestral heritage will not just disappear. Based on the results of the analysis and design of the system that was built, it can be concluded that the system design that was formed provides a lot of literature and references that discuss the Minangkabau songket motif as a source in this study.

Furthermore, the system that has been designed in the discussion of the web-based Minangkabau Songket Motif Digital Catalog Information System provides an alternative in information management. The Minangkabau Songket Motif Digital Catalog System can also make it easier for someone to find the motifs and meanings contained therein.

\section{References}

[1] Sulastri, S., Andriani, C., \& Fitria, Y. (2018). SOSIALISASI DAN PELATIHAN KEPEMIMPINAN MINANGKABAU UNIVERSAL UNTUK PEMUDA DI KELURAHAN PASIE NAN TIGO, KECAMATAN KOTO TANGAH, KOTA PADANG. UNES Journal of Community Service, 3(2), 062. doi:10.31933/ujcs.3.2.062-069.2018

[2] Nawir S. (2007), "Songket Silungkang (Sawahlunto Sumatera Barat)", Citra Kreasindo, Jakarta

[3] Firman, F.-. (2018). PEMAKAIAN SONGKET DALAM PERUBAHAN PERANAN PEREMPUAN MINANGKABAU DI MASYARAKAT. doi:10.31227/osf.io/urxbq

[4] Nusyirwan A. (1982), "Ragam Hias Songket Minangkabau", Proyek Pengembangan Permuseuman Sumatera Barat, Padang

[5] Yandri, Y. (2014). TENUN SONGKET PANDAI SIKEK DALAM BUDAYA MASYARAKAT MINANGKABAU. Humanus, 13(1), 28. doi:10.24036/jh.v13i1.4094

[6] Christyawaty, E. (2018). Pengaruh Motif Hias Tradisi Megalitik Pada Motif Songket Minangkabau. Berkala

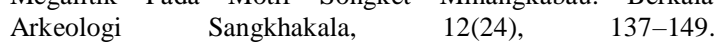
doi:10.24832/bas.v12i24.214 
[7] S Rosa dan M.Shalahuddin. 2015. Rekayasa Perangkat Lunak [13] Sutabri, Tata. 2012. Konsep Sistem Informasi. Yogyakarta : Terstruktur dan Berorientasi Objek. Bandung: Informatika Bandung.

[8] Agung, Leo, 2009, Langsung Bisa Membangun Website Professional dengan CS4, PHP, dan MySQL, Yogyakarta, Andi

[9] Antonius, Nugraha Widhi Pratama. 2010. Codeigniter: Cara Mudah Membangun Aplikasi PHP. Jakarta Selatan : Mediakita

[10] Hidayatullah, Priyanto, dan Jauhari Khairul Kawistara. 2017. Pemrograman WEB. Bandung. Informatika Bandung.

[11] Kustiyahningsih, Yeni. Devie, Rosa Anamisa. 2011. Pemograman Basis Data Berbasis Web Menggunakan PHP \& MySQL. Yogyakarta : Graha Ilmu

[14] Tohari, Hamim. 2014. ASTAH (Analisis Serta Perancangan Sistem Informasi Melalui Pendekatan UML). Yogyakarta : Andi.

[15] Yuhefizar, Mooduto, \& Hidayat, R. (2009), Cara Mudah Membangun Website Interaktif Menggunakan Content Management System Joomla Edisi Revisi, Jakarta, PT Elex Media Komputindo

[16] Pendit PL. (2008), "Perpustakaan digital dari A sampai Z", Jakarta: Cita Karyakarsa Mandiri

[17] Poerwadarminta W.J.S. (1976), "Kamus Umum Bahasa Indonesia”, Balai Pustaka, Jakarta

[12] Sidik, Betha. 2012. Pemrograman Web Dengan PHP 7.

Bandung: Informatika 